\title{
МЕМУАРНА ВЕНЕЦІЯ ОСИПА НАЗАРУКА В КОНТЕКСТІ СВІТОВОГО ПИСЬМЕНСТВА
}

\author{
МАРІЯ ФЕДУНЬ \\ Івано-Франківський обласний інститут післядипломної педагогічної освіти, \\ Івано-Франківськ - Україна \\ WENECJA W PAMIĘTNIKACH OSYPA NAZARUKA \\ W KONTEKŚCIE LITERATURY POWSZECHNEJ \\ MARIA FEDUŃ \\ Iwano-Frankiwski Instytut Doskonalenia Nauczycieli, \\ Iwano-Frankiwsk — Ukraina
}

\begin{abstract}
STESZCZENIE. W artykule przeanalizowano pamiętnikarski opis Wenecja na tle literatury powszechnej ukraińskiego pisarza, doktora prawa kościelnego i świeckiego Osypa Nazaruka. Autorka porównuje zachodnioukraiński cykl podróżny z Podróżq do Włoch J.W. Goethego, a także dziełami rosyjskich pisarzy o Włoszech. Analiza potwierdza, iż Wenecja Galiczanina O. Nazaruka znakomicie wpisuje się w literaturę europejską, i jednocześnie świadczy o oryginalności twórczości pamiętnikarskiej Ukrainy Zachodniej pierwszej połowy XX wieku.
\end{abstract}

\section{MEMOIR VENICE OF OSYP NAZARUK IN THE CONTEXT OF THE WORLD OF WRITING}

\author{
MARIA FEDUN \\ Ivano-Frankivsk Regional In-Service Teachers Training Institute, \\ Ivano-Frankivsk - Ukraine
}

\begin{abstract}
The article examines memoirs description of Venice by Ukrainian writer, Dr. of Secular and Ecclesiastical Law, Osyp Nazaruk in the context of world literature. The author compares the above mentioned West Ukrainian traveling series with Italian Journey by J.-W. Goethe, works of Russian writers of Italy and concludes: Venice by a Galician O. Nazaruk originally blended in European literature array and showed identity of memoir thought of Western Ukraine in the first half of the twentieth century.
\end{abstract}

I

талія здавна чарувала красою природи й архітектури, витворами поезії, малярства і под., тому й не дивно, що впродовж довшого часу італійська тема приваблювала європейських письменників, зокрема й німецького мислителя та поета Йоганна-Вольфганга Гете. Назвемо й російських авторів - графиню А. Толстую (німецького походження), яка, перебуваючи в Італії, залишила щоденник, що манерою викладу близький до путівника барона й дипломата А. Крюденера, який вів Щоденник подорожі в 1786 р. по Італії. Відповідний внесок в італійську тематику зробили також П. Куліш, Ю. Федькович та інші українські письменники. Зрештою, відомі спогади росіянина Максима Горького про перебування на Капрі нашого М. Коцюбинського. До числа тих, кого приваблювала тема Італії, можемо зарахувати також українських митців слова перш. пол. ХХ ст. й, насамперед, мемуаристів - М. Грушевського, М. Островерху, О. Назарука та ін. Цей список можна продовжити. 
Прикметно, що зачудування названого німецького поета Італією відображено в дослідженнях росіян А. Анікста, С. Тураєва зокрема, а італійська проблематика - у російських дослідників К. Вьйолле, Є. Гречаної.

Що ж до комплексного вивчення цієї проблеми у західноукраїнській літературі перш. пол. XX ст., що за своєю суттю була соборною, то до неї науковці практично не зверталися. Однак, як засвідчують авторські пошуки, постать Й.-В. Гете цікавила українських письменників, насамперед галичан - I. Франка, О. Пристая, О. Назарука та ін., а сам О. Назарук (роки життя: 1898, м. Бучач на Тернопільщині, Україна - 1940, м. Краків, Польща) - державник і націоналіст, доктор світського та церковного права, письменник і політик, культуролог та військовий кореспондент не лише вчився на вершинному вмінні Й.- В. Гете „бачити час" (М. Бахтін), але й часто цитував, подавав у канві своїх праць переклади його творів, зокрема у спомині про стрільців Над горішньою Стрипою галицький автор, роздумуючи про поезію як вияв почуттів, наводить слова Й.-В. Гете про те, що на всі покоління людей однаково впливають чотири складники - любов, дзвін кришталевих чаш, наповнених вином, брязків військової зброї, ненависть до того, хто на неї заслуговує. Як і німецький поет, О. Назарук часто звертався до алегорії, уживав цей художній засіб у мемуарах. У Венеціï він осягнув названий літературознавчий концепт алегорії, простежив це мистецьке явище на прикладі української народної пісні Ой копав я криниченьку... Як і німець Й.-В. Гете, який в Італії взявся до вдосконалення свого малярського таланту, галицький письменник звертав увагу на художні полотна італійських митців (картина Тінторетто навіть викликала в нього своєрідні політичні та суспільствознавчі, культурологічні рефлексії, які він адресував українським діячам).

Оцінюючи доробок німецького поета, який, до слова, подібно до Осипа Назарука, свого часу зробив політичну кар'єру - обіймав крісло міністра, С. Тураєв підкреслив, що в Італії (Римі) Й.- В. Гете пройшов складний процес переосмислення ідейно-естетичних позицій, а його Подорож до Італї сприймаємо як художньо-публіцистичний документ, що відобразив важливий етап в духовному розвитку поета ${ }^{1}$. У центрі уваги Й.-В. Гете природа, звичаї народу, пам'ятки мистецтва. Та важливим $\epsilon$ те, що в згадуваному творі німецького автора гостро „на весь ріст поставлена проблема національного характеру”2. Поет і мислитель бачить динаміку розвитку культури в коливаннях художніх смаків, величній простоті. Саме останню (не без впливу німецького поета) визначить і український публіцист О. Назарук у спогадовому творі як один зі складників художньої майстерності.

Мемуарна Венеиія О. Назарука, подібно до італійської подорожі Й. В. Гете, теж публіцистично насичена, однак твір першого (названого вище) автора це політичний маніфест українця, який ставить своїй нації гострі питання: чи думає іï пересічний представник над тим, кого допускає до політичного поля, чи шанує свій провід тощо. У площині роздумів галичанина - думки про релігію в сенсі сповідування ії державними мужами, передбачення розвалу СРСР („це переходова поява”) як такого, що базується на атеїзмі. Прикметно, що релігійний дискурс надавав текстам денників елементів духовних щоденників, був доволі частим і в російських авторів (зокрема А. Колечицької), які порівнювали візантійські та російські церкви.

${ }^{1}$ С. В. Тураев, Гете и формирование концепции мировой литературы, отв. ред. Е. М. Мелетинский, Москва 1989, с. 169.

${ }^{2}$ Там само, с. 174. 
Й.-В. Гете, що, як було зазначено, захопився в Італії малярством, вбачав обумовленість творчого процесу різними причинами - особливостями таланту, попередниками та вчителями, часом й місцем творчості, замовниками і под. Оглядаючи Венецію, зокрема катедру Святого Марка, О. Назарук, теж розмірковує про те, як відбувався процес зведення святині. До слова, ця проблема проблема будівництва (на противагу руїнництву) - наскрізно проходить крізь низку мемуарних творів О. Назарука, зокрема й подорожню Святиню мормонів. А щодо малярських полотен, то наш мемуарист за допомогою пера передає не лише враження про побачені шедеври, але й власні асоціації. Розповідаючи про вже згадувану картину Тінторетто на військову тематику, автор на мить повернувся у свою юність. У певний момент йому здалося, що не він дивиться на це полотно, а воно на нього. У мемуари входить поетика повсякдення: мемуаристу згадався його агітаційний виступ перед селянами в селі Возилові (Україна, Тернопільська область) над Дністром (тематику промови автор, на жаль, не наводить), коли натовп вп'явся очима в нього, студента, й він розгубився. Лише сильним „зусиллям ума” оратор, який удома добре вивчив промову, однак не зафіксував ії на папері, „пов’язав прірву” у виступі. Отже, визначаємо поетику повсякдення й вловлюємо культурологічні рефлексії щодо підготовки публічного виступу (до слова, у нашого краянина є й окрема праця Культура публічного виступуз $)^{3}$.

Письменник, як видно з тексту Венещії, на однин рівень ставить значення малярства й мемуарів у житті нації, указує на зв'язок між історичними працями (історія - „учителька життя”) та мемуарами („підстава для неї”), звертає увагу на значення й роль промов політичних діячів і політиків, що, на його погляд, не повинні оперувати нудними й „зужитими” фразами. Звертаючись до історії свого народу, мемуарист не забуває й повчальних сторінок історії Венеції, згадує мемуари Давнього Риму і под. Мемуари О. Назарука, як і тексти спогадів більшості тогочасних західноукраїнських авторів, виконують дидактичну функцію. Це нагадує повчальні слова самого Й.-В. Гете: „Коли народу вишукано нагадують про його минуле, то це завжди викликає приємні відчуття; ми радіємо добродійству наших предків і сміємося з їхніх недоліків, уважаємо, що ці недоліки давно вже здолані; тому таке зображення забезпечило собі інтерес й успіх, які я неодноразово відчував..."4. Як і „зображенням” О. Назарука, який буквально змережив рядки венеційських спогадів згадками з української історії, зокрема, письменник навів приклади спорудження церков гетьманами I. Мазепою, Б. Хмельницьким, пригадав сторінки з історії козацтва і под.

А щодо самої Венеції, iї собору й площі Святого Марка, то їх опис загалом є традиційним для багатьох творів мемуаристів, зокрема росіянок. Так, Н. Куракіна, подібно як й інші подорожуючі по Італії, ідентично змальовує катедру Святого Марка, площу, іiі аркади та галереї, міст Ріальдо, церкви й картини великих майстрів, що їх прикрашають (XIX ст.). А княгиня Єлена Павловна (уроджена Фредеріка-Шарлотта-Марія, принцеса Вюртемберзька, 1806-1873), як зауважує К. Вйолле, акцентує почуття суму, що охоплює ії під час споглядання могутнього колись міста з його покинутими замками й вічною тишею, зауважує, що собор Святого Марка побудований у тому ж грецько-візантійському стилі, що й російські церкви - сприйняття чужого відбувається через подачу свого

${ }^{3}$ Див.: М. Федунь, Публіцистика та мемуари Осипа Назарука, Івано-Франківськ 2006, c. $19-34$.

4 Й.-В. Ге те, Из „Поэзии и правдыл”, [в:] Е г о ж е, Избр. философ. произвед., под. ред. Г. А. Курсанова, А. Гулыги, Москва 1964, с. 203. 
„я”, призму особистого й національно ідентичного тому, хто пише спогади. А подорожні щоденники, як правило, починають з опису моменту від'їзду автора. Загалом, ,записи окреслюють особливий особистий простір”5.

У О. Назарука ж, окрім традиційного опису міста, вступні слова до Венеuіï містять іронічну оцінку ментальності українців: він із сарказмом зауважує, що галичани їдуть у Європу аж тоді, коли виникає потреба лікуватися, і саме в той час ми й оглядаємо ії пам'ятки. Із хворобою хребта, як сам зазначає, письменник їде в Італію на лікування, а побачивши красу Венеції, уважно занотовує враження, вирішує розповісти про них своїм краянам. Політичні рефлексії, екскурси в минуле (не лише італійське, але й наше) стають наскрізною ниткою його записів.

О. Назарук, як й інші мандрівники, майстерно змальовує „місто серед моря”, передає перші враження, коли в'їжджає у Венецію, розповідає, як на гондолі пливе до площі Святого Марка та його катедри, спостерігає мости й будинки. Саму ж святиню мемуарист змальовує в контрастності зовнішнього вигляду, інтер'єру, тому рефреном проходить вираз „Мир Тобі, Марку, мій Евагелисте" й слова митців, які споруджували цей собор та бажали, щоб під час знайомства з ним у пересічного подорожуючого, пілігрима виникало здивування ${ }^{6}$ : „Хочемо такої церкви, аби була подібна до візантійської, але аби нам ніхто з візантійських послів не мав права казати, що ми їх наслідували й аби ті драбуги лиш роти роззявили, як побачать нашу церкву"”. Здивування не полишало письменника й упродовж оглядин собору, що вилилося в галицького мемуариста в репліку: „...ми мали довго державу серед хвиль Дніпрових, але вона не збудувала ні одного кусника муру, ні для нас на землі, ні для Господа Бога на небі"в.

О. Назарук залишився одним із тих, хто, виявляючи себе повноцінним європейцем, був, як наголошував П. Карманський у Слові вияснення до Української Богеми, „нам рідні, не скажені модною сьогодні парижоманією і манією пози європейськости, якою сьогоднішнє покоління так залюбки анонсує свій крам "made in Galicia". Вони були такими, якими виліпив їх 3 нашої галицької глини Сгова галицького загалу... Любили свій рідний загумінок, дорожили тим, що позитивного й негативного найшли на ньому, бо знали ціну приповідки: «ворона, й за море літала, та все чорна повертала»"”. О. Назарук, подібно до молодомузівця П. Карманського, передусім був українцем.

У мемуарному творі про подорож Венецією О. Назарук показав, „як він склав собі погляд на світ і людей”10 та як філософськи відобразив це крізь релігійний ракурс бачення.

Ставлячи завдання „по правді висказати свою думку”"11, автор Венеції одразу ж усвідомив, що пережите в „місті серед моря” „експресіонує”" його думку. Для увиразнення побаченого О. Назарук удався до порівняння святинь Ве-

${ }^{5}$ К. В ьолле, Е. Гречаная, Дневник в России в конце XVIII-первой половине ХІХ в. как автобиографическое пространство, [в:] „Известия Академии Наук” 2002, сер. лит. и яз., т. 61, № 3 , с. 27 .

${ }^{6}$ Примітка. Тут і далі цитати із джерел Галичини перш. пол. ХХ ст. подаємо відповідно до сучасного правопису, однак максимально зберігаючи стиль автора.

${ }^{7}$ О. Н Н азару к, Венеиія. Катедра св. Марка. Палата дожів, Львів 1934, с. 12.

${ }^{8}$ Там само, с. 24.

${ }^{9}$ П. Карман сь ки й, Украӥнська Богема, упорядкув., післямова і примітки П. Ляшкеви ча, Львів 1996, с. 25.

${ }^{10}$ Й.-В. Ге те , Из „Поэзии и правдыл”..., с. 166.

${ }^{11}$ О. Наз арук, Венеиія..., с. 9.

12 Там само, с. 18. 
неції з тими, які бачив раніше (катедри св. Стефано у Відні, Волоської церкви у Львові, собору в Філях - Німеччина), до проведення паралелей між чужою й нашою історією. Зокрема, щодо спорудження святинь представниками Венеції і працею П. Конашевич-Сагайдачного, який „урятував Польщу під Хотином” та „поставив” першу друкарню на Великій Україні. Зауважений автором „закон контрасту” дає змогу йому — людині „з країни верби і недолі” (О. Назарук) - протиставити „вицяцькувану і всім, особливо ж багатством, переладовану святиню"13 катедри Марка, розважливість державних мужів Венеції, збірки промов і листів чужинців нашій маломовності, іноді невмотивованим думкам деяких українських „нігілістів і руїнників”14, „трубадурів руїни”15, якими бачить він соціалістів. Рефреном проходить фраза: „Мир Тобі, Марку, мій Евангелисте!", що потверджує гуманістичне сприйняття пережитого. I разом з низкою наведених притч, уривками з Євангелія - віру в розважливість коли не сучасних авторові, то наступних поколінь української інтелігенції. Подорожні описи О. Назарука місцями межують зі споминами (автор пригадує події 30-річної давності, коли „слухав виклади про Венецію у Віденськім університеті”"16) і денником. На останнє вказують часові означники: „12 липня 1933”"17, „Дня 13 липня 1933 р. о год. три чверті на 10 рано..."18 та ін. Мемуарна Венеція О. Назарука насичена записами, звітами про пережите повсякденне. Маємо ретельні щоденникові записи, де автор пише, коли конкретно поселився в готелі, зафіксовано навіть конкретну годину події, яка відбулася, що засвідчує гнучкість мемуарного жанру.

Подаючи „думки політичні” щодо руїнників, О. Назарук вносить у Венецію чимало белетристичного й публіцистичного матеріалу. А, як відомо, жанрова еволюція в мемуаристиці зумовлена „зближенням художнього, публіцистичного й наукового образів"19 (Я. Явчуновський). В О. Назарука це відбувається за рахунок метафоризації прислів'їв і приказок: „Всюди добре, а в гостях у Божих творивах таки найкраще"20, „3 порожнього не наллєш і нічого не вичитаєш"21 і под. Для увиразнення своїх політичних думок автор використовує синекдоху, коли критикує „історію публічних виступів всяких Вітиків, буковинських Безпалків, галицьких Сіяків, наддніпрянських Скрипників і всяких інших Юринців, Гадзінських і Лозинських"22, звертається до Володимирів Вікторовичів, які пропагували соціалістичну ідею. Мемуарист оригінально вносить біблійний елемент: „...нарід... може мати безліч Донцових, Палієвих і всяких інших вічно молодих редакторів „Наших Кличів” і при тім може «відроджуватися», поки архистратиг Михаїл не затрубить, щоб іти вже на Йосафатову долину”23. Мемуарист розмірковує про потребу формування національних структур влади, іiі пошану з боку загалу тощо, з чим варто погодитися.

\footnotetext{
13 Там само, с. 29.

${ }^{14}$ Там само, с. 39.

15 Там само, с. 35 .

16 Там само, с. 41.

${ }^{17}$ Там само, с. 3 .

${ }^{18}$ Там само, с. 43.

19 Я. И. Я в чу н о в с к и й, Документальные жанры: образ, жанр, структура произведения, под ред. П. А. Бугаєнко, Саратов 1974, с.80.

${ }^{20}$ О. Н Нзарук, Венеиія.., с. 264.

21 Там само, с. 108 .

22 Там само, с. 123.

${ }^{23}$ Там само, с. 109.
} 
Предметом уваги О. Назарука стає політика („політика - се бритва”24) та інші суспільні явища. Мова мемуарного твору викривальна: „.. я дякував Богу, що я був у Венеції, а не на Соловках, у страшній «Венеції» терпінь народа мого..."25. Автор апелює до читачів, напр., до брата Івана. Дає різкі характеристики національним діячам, порівн.: „Донцов - се нігіст і руїнник, а не проповідник і ідеолог. Котра нація і котра молодь хоче зійти на пси, то біжить за такими «ідеологами» ${ }^{26}{ }^{27}$. Підсиленню публіцистичної спрямованості мемуарів Венеція сприяє образ Азазеля - „страшного демона руїни”28, який „вже раз танцював вздовж великого сибірського шляху"29. Автор асоціює його з ідеєю соціалізму. Письменницьке вміння „глибоко запускатися в нетрі української душі й історіі”’30 дає Назарукові можливість змалювати образ Марка Проклятого, який протиставлений Маркові Евангелисту. Демона змальовано як „того, що несе в торбі голову рідної матері, котру сам зарізав, і по коліна западається в землю під тягарем іiі... Але він ще не був найгірший з тих, яких видала медом і молоком пливуча земля, де вишневі сади як сніг цвітуть..."31. Значно гіршими постають в очах публіциста ті, які „рідну матір зарізали і кажуть до сеї пори, що зробили се ,задля високої ідеі”’, розуміється соціалістичної”з2. Такі автори були й серед деяких тогочасних редакторів „40-мільйонного народу” України.

Сатиричний пафос наведеного уривка аналогічний до того, що його має Meisterwerk (шедевр) М. Хвильового Я (Романтика), один із небагатьох творів „трагічного звучання, у яких із вражаючою художньою силою були б відтворені роздвоєння реальності та ідеалів” і якому характерна „трагічна розв'язка глибокого внутрішнього конфлікту ідеї і совісті, України і комуніста, художника і громадянина" 33 .

О. Назарук 1934-го по-своєму оцінює рішення Хвильового звести рахунки 3 життям: „...тепер наші руїнники, наробивши страшної шкоди на спілку з наїзниками, стріляються один по другім, замість боротися з ворогом... I се наша «патріотична преса» величає як “найлучший протест”, який буцімто “поцілить червону Москву!..” Чи не до решти здурніли? Та ж червона Москва рішучо нічого проти того не має, аби ми всі вистрілялися до ноги. Та який се протест? Се ж дезертирство..."34. Так автор цитованих слів акцентував потребу активних (збройних) форм боротьби.

Позиція О. Назарука щодо формування політичної філософії суспільства й держави загалом подібна до позиції іспанського культурфілософа, публіциста, суспільного діяча, представника екзистенціалізму Ортеги-і-Гассета. Аналогічно до Ортеги, який „взявся за духовну перебудову Іспанії” „обставини його — іспанські, а погляд — європейський” (Й. Лось) ${ }^{35}$, за таку ж духовну перебудову (України) узявся й О. Назарук, і погляд у нього теж був європейський.

${ }^{24}$ Там само, с. 185.

${ }^{25}$ Там само, с. 295.

${ }^{26}$ О. Наз арук, Венеиія..., с. 39.

${ }^{27}$ Там само, с. 102.

${ }^{28}$ Там само, с. 105.

${ }^{29}$ Там само, с. 39.

${ }^{30}$ Там само, с. 25.

${ }^{31}$ Там само, с. 25.

${ }^{32}$ Там само, с. 25.

${ }^{33}$ Див.: М. Жулинський, Передмова, [в:] Микола Хв ильов ий, Твори, у 2 томах, Київ 1990.

${ }^{34}$ О. Наз арук, Венеиія..., с. 38.

35 Див.: Й. Лось, Формування політичної філософії суспільства і держави ресурсами публіцистики, [в:] Вісник Львівського університету, сер. журналістика 2007, вип. 30, с. 12-35. 
У нашого мемуариста вловлюємо турботу про людину, культуру, націю, якій він ставив діагноз (,„Здається, що причина тої нашої німости коріниться в лінивстві думки і тупій гордости, нероздільно сплетених між собою"36), тому й давав свої рецепти для зміни довкілля (,Влада, котра чується зовсім безпечна серед людського горя і біди, — се певний і нехибний знак зіпсуття..." ${ }^{37}$ ).

Отже, мемуарна Венеція галичанина О. Назарука, одного 3 найбільших українських інтелектуалістів перш. пол. XX ст., як зазначили сучасники в опублікованому на його смерть некролозі („Краківські вісті”, 1940), оригінально вписалася в європейський літературний контекст подорожнього письменства перш. пол. ХХ ст.

Цей твір засвідчив самобутність західноукраїнської спогадової думки, що в перші десятиріччя зазначеного століття прийшла на шляху своєї еволюції до вершинних витворів. Саме такими небуденними стали мемуарні подорожні перлини філософського-публіцистичного звучання, написані народженим в Україні та вболіваючим за ії долю спогадувачем і державником Осипом Назаруком.

${ }^{36}$ О. Н Назарук, Венеиія..., с. 49.

${ }^{37}$ Там само, с. 74. 